\title{
Manuscript Collections: The Archival Collections at the Center for Dubuque History
}

\section{Michael D. Gibson}

THE MAGNIFICENT HILLS and deep valleys of the Dubuque area are a testament to the last glacial episode, when the descending ice cap split and went around this "driftless area," leaving one of the greatest lead deposits then known in the world. Mining in this area goes back three hundred years. Very likely some of the shot fired from American muskets in the revolutionary war came from the Dubuque area. A few years after the close of the war Julien Dubuque established himself near the future site of the city that was to bear his name. For twenty-two years he and the Mesquakie Indians mined lead, engaged in the fur trade, raised livestock, and farmed in the area. Educated, suave, and enterprising, Julien Dubuque became the most celebrated personage on the upper Mississippi River.

Following the Black Hawk War in 1832, the Dubuque area was opened to white settlement. By 1840 there were more than three thousand residents in the county. Foreign immigrants German, Irish, and British - poured into the frontier town which was incorporated in 1837 . In the past 150 years, as mining declined and agriculture, lumbering, and manufacturing developed, the community we know today was formed. Dubuque is Iowa's oldest city and remains truly the Key City in the history of the Hawkeye state.

Documentation of all aspects of Dubuque's colorful past can

THE ANNALS OF IOWA 50 (Spring 1990). (C) The State Historical Society of Iowa, 1990. 
be found in the Center for Dubuque History at Loras College, which preserves many of the records, documents, and books detailing the history of the tri-state region of the upper Mississippi River. The center was founded in 1976 by Loras College librarian Robert Klein and history professor Thomas Auge. Its collections are housed in the Wahlert Memorial Library on the Loras College campus, the first college in the state of lowa. The purpose of the center is to provide leadership and direction to faculty, students, and the general public in the systematic study of local and regional history. It seeks to collect, organize, and provide materials for research by interested individuals and groups; to conduct research and publish studies of local interest; and to offer special courses, workshops, lectures, and other forms of instruction for interested persons.

To help meet these objectives the center has built an archival collection of research materials related to the city and county of Dubuque, the surrounding counties of Jackson, Delaware, and Clayton, and the tri-state region, including Galena and East Dubuque, Illinois, and the lead-mining region of southwestern Wisconsin as far north as Platteville. Included in this archival collection are manuscripts and archives (380 linear feet), published sources ( 85 linear feet), maps and cartographic material (10 linear feet), about 8,000 photographs, 400 picture postcards, nearly 100 oral history interviews, 900 rolls of microfilmed newspapers, and dozens of audio visual materials. Supplementary source material is available in the adjoining Wahlert Memorial Library, which contains more than 380,000 items. The library is also a federal and state governmental document depository.

There are many varied collections and types of material for the researcher to use in the center. One of the more significant collections is the city council proceedings from 1837 to 1970 ( 68 cubic feet). Many interesting petitions are included, such as those concerning hogs running in the streets and the public health hazards of standing bodies of water. The earliest petition is in the French language, showing the French influence in the city. One will notice the names of many prominent Dubuquers: the Langworthy brothers; Stephen Hempstead, Iowa's second governor; Judge Thomas Wilson, a justice on Iowa's first territorial supreme court; and Senator William Boyd Allison, who served the longest congressional term to date of anyone in the nation. Many years 
ago a student began indexing these documents by names of individuals, by businesses, and by subject, but indexing has been completed only up to 1860 . For students and researchers interested in city government, these original, holograph documents are an extremely valuable primary source.

Another primary source is the collection of Dubuque County records (93 cubic feet), which were salvaged from the county courthouse in the late 1970s. Included in this collection are the earliest tax lists (1853-1910) arranged by township and comprising some 325 volumes. These have been microfilmed by the Church of Jesus Christ of Latter-day Saints. Also included are assessment books, auditor's reports, mortgage books, jail registers, probate calendars, and other records comprising another 230 volumes. The tax lists are especially useful for genealogists, but also for historic preservationists. While not foolproof, tax lists often are helpful in determining when a building was constructed.

One of the largest collections in the center is the "vertical file" of material relating to Dubuque and the immediate vicinity $(90$ cubic feet). Here are housed, in acid-free Hollinger boxes, published articles, newspaper clippings, pamphlets, leaflets, reports, and business records containing the "bits and pieces" of Dubuque's past. Arranged alphabetically, there are more than 140 topics ranging from banks to weather. A list describes the contents of each folder. The master list has been computerized, and a hard copy is generated and updated periodically.

In the map and lithographic collection ( 22 cubic feet) one will find not only the earliest maps of the area from the seventeenth century, but railroad maps, highway maps, atlases, platbooks, maps of mining activities, geological surveys, and topographic maps. In addition, there are numerous maps of the city, including up-to-date plat maps showing all city lots and streets. Various planning and zoning maps and Iowa Department of Transportation maps are a part of the collection. There are numerous lithographs, birds-eye views, artistic renderings of buildings, architectural and engineering plans for bridges (including the structural plans for the Dubuque-Wisconsin Bridge Company, the last privately owned bridge company in eastern Iowa) and other structures.

The photograph collection is one of the most highly regarded and heavily used of all of the collections. Nearly eight thousand 
images constitute this significant collection, which provides valuable visual images of Dubuque as far back as the 1880s. The $8 \times$ 10 and $5 \times 7$ black-and-white prints that form the major portion of the collection are cataloged according to subject. There are also original photographs and some colored prints and slides. Here the subject headings range from aerial views to transportation with all sorts of topics in between, including banks, convents, hospitals, parades, parks, schools, steamboats, and so forth. All prints have been photocopied and are filed by subject in books for browsing. The prints can be pulled to show details. Negatives are stored in another location off the campus, and photos are available for reproduction for a fee.

One of the most significant photo collections is the one donated by Dubuque industrialist William Klauer. It contains several hundred images of Dubuque working women and men. The original glass-plate negatives were produced in 1912 by an unknown photographer who was permitted to take the photos in the various factories and businesses of Dubuque. In 1985 the collection became the basis for a traveling exhibit created by Mary Allison Farley and titled "Iowa Women in the Workplace." Since 1985 the exhibit has toured throughout the state of Iowa and has been well received. It is still available for loan at no charge (except freight) to interested groups.

In addition to the photographs, more than four hundred picture postcards ( 1 cubic foot) are arranged in the collections by topics and filed in a metal card file. Topics range from scenic views of the Mississippi River from Eagle Point Park and the trolley cars at Union Park to the early bridges and many of the early buildings of the community.

Besides the primary sources listed above, the center also houses city directories dating back to 1856 , along with a large number of secondary sources (42 cubic feet), including biographies, family histories, works by Dubuque authors, theses and dissertations on local topics, and general histories. Loras College also has a complete microfilm collection of Dubuque newspapers dating to the first newspaper printed in Iowa, the Dubuque Visitor, beginning in 1836. The Works Progress Administration (WPA) created a partial index to some of these newspapers in the 1930s. A more complete index is at the Carnegie-Stout Public Library in Dubuque. There are also microfilm copies of several 
German-language newspapers that were published in Dubuque as well as the Catholic newspaper, The Witness. For genealogists, there is an extensive obituary index for the Dubuque newspapers which is maintained on a monthly basis by the Key City Genealogical Society and is up-to-date. Also on microfilm are some miscellaneous records from the Office of Indian Affairs (1824-1880) which contain data relating to Indian activity in the area.

All of these resources are supported by a 380,000-item academic library that is strong in American history. The periodical collection contains historical journals from many of the surrounding states. There is also a vast government document collection and an excellent set of reference tools for the researcher. The U.S. Serial Set of some thirteen thousand volumes dates back to 1817 , and contains many useful items for the local historian. All of these factors make the Center for Dubuque History a useful research center for anyone interested in the history of the upper Mississippi Valley and especially the Dubuque region.

The resources and facilities of the Center for Dubuque History are open to the public. Anyone interested in the local history of this area is welcome to use the materials at the center, but should be aware that items do not circulate. Photocopy service is available. Because of limited staffing, the center must charge a fee for major research. The center is open only limited hours which vary each semester. Anyone planning to visit should phone in advance (319)-588-7125. A free brochure, or additional information, may be obtained from: Archivist, Center for Dubuque History, Wahlert Memorial Library, Loras College, P.O. Box 178, Dubuque, lowa 52004-0178. 
Copyright of Annals of Iowa is the property of State of Iowa, by \& through the State Historical Society of Iowa and its content may not be copied or emailed to multiple sites or posted to a listserv without the copyright holder's express written permission. However, users may print, download, or email articles for individual use. 